\title{
EXTRA-CORPOREAL CIRCULATION AND HEART SURGERY
}

\author{
BY \\ CH. DUbOST, R. HEIM DE BALSAC, R. DE WALL, C. LENFANT, J. GUERY, \\ J. PASSELECQ, M. WEISS, AND J. ROUANET
}

From the Surgical Centre Marie-Lannelongue (Dr. Sauvage), Cardiological Department (Professor Dubost), the National Centre of Blood Transfusion (Drs. J. P. Soulie and Cagnard), with the help of the Social Security and of the National Institute of Hygiene (Professor L. Bugnard)

Received August 10, 1956

During the last 18 months, we have been investigating the various methods of open heart surgery at the Marie-Lannelongue Surgical Centre. Trials of hypothermia proved unsatisfactory, so we resorted to methods involving an extra-corporeal circulation, employing the simpler systems that use a relatively small flow. In most methods of perfusion during exclusion of the heart and lungs from the circulation, the guiding principle is determination of the minimum blood flow for body weight necessary to maintain life, and this is based on the azygos factor of Andreasen and Watson (1952). We have experimented with the crossed-circulation method of Lillehei and his fellow workers, with the biological oxygenator of Campbell, and with different methods of arterial blood transfusion either alone or combined with hypothermia. In the course of these trials, Lillehei and Dewall perfected their new oxygenator, the advantages of which appealed to us at once so that we adopted it in preference to other systems.

\section{The Lillehei-Dewall Pump-oxygenator System}

The system consists of a venous circuit that directs blood from the vena cava to the oxygenator, an arterial circuit that directs oxygenated blood to the aorta, and a finger-type pump that propels the blood in both circuits. Details of the apparatus were shown in the film.

The venous blood is rapidly oxygenated by intense bubbling with oxygen, and the bubbles are then broken up by passage through a tube coated with silicone, and allowed to escape. The oxygenated blood, completely freed from bubbles, accumulates in a reservoir kept warm by a waterbath at $37^{\circ} \mathrm{C}$. The arterial circuit starts from this reservoir and includes a filter that permits a rapid flow.

The oxygenator tubes, the reservoir, and the venous and arterial circuits are made of transparent plastic, simply fitted together, the only mechanical device in the system being the pump. We have followed closely the technique devised by Lillehei and Dewall, and we are indebted to Dr. Dewall for his help during a personal visit to our laboratory.

We have introduced certain modifications of the original apparatus which seem to be of value. (1) By employing twin oxygenators, the capacity of the system has been increased from 600-800 $\mathrm{ml}$. at the start successively to $1000-1800 \mathrm{ml}$. per minute, so that the method is now applicable to adults as well as children. (2) In order to reduce blood loss from hæmorrhage and to diminish the need for multiple transfusions from different donors, we have added another circuit by which blood in the heart cavities, or returning to them during operation, is collected by an aspirator and returned to the oxygenator. 


\section{EXPERIMENTAL RESULTS}

The pump-oxygenator has been used in 80 dogs. After clamping the venæ cavæ, we have performed cardiotomies involving either the right atrium or the right ventricle, and sometimes both simultaneously. The heart was kept open for 13-40 minutes, and the survival rate was about 80 per cent. All deaths resulted from surgical causes and not from defective operation of the apparatus.

We started with small dogs (up to $20 \mathrm{~kg}$.) using relatively small perfusions of up to $700 \mathrm{ml}$. per minute, and later we used larger dogs $(20-40 \mathrm{~kg}$.) increasing the perfusion above the minimum up to $44-58 \mathrm{ml}$. per $\mathrm{kg}$. per minute, so that perfusions of $1800 \mathrm{ml}$. per minute were attained. These good results ( $80-91 \%$ survivals) permitted us to apply the procedure to human surgery.

\section{Clinical Results}

Open heart surgery involves much organization and a large team of workers, so that so far we have operated only on five patients, details about whom are given in Table I.

TABLE I

Operated Patients

\begin{tabular}{|c|c|c|c|c|c|c|c|}
\hline $\begin{array}{l}\text { Case } \\
\text { num- } \\
\text { ber }\end{array}$ & Age & $\begin{array}{l}\text { Weight } \\
\text { (kg.) }\end{array}$ & $\begin{array}{l}\text { Clinical diagnosis and } \\
\text { operation findings }\end{array}$ & $\begin{array}{l}\text { Surgical } \\
\text { corrections }\end{array}$ & $\begin{array}{l}\text { E.C.C. } \\
\text { duration } \\
\text { (minutes) }\end{array}$ & $\begin{array}{l}\text { Flow } \\
\text { in } \\
\mathrm{ml} . / \mathrm{mn} .\end{array}$ & Results \\
\hline 1 & 7 & $19 \cdot 6$ & $\begin{array}{l}\text { ASD and large ostium } \\
\text { primum }\end{array}$ & Closure & 16 & 580 & $\begin{array}{l}\text { Death 24th hour (hæmoly- } \\
\text { sis and anuria) ostium } \\
\text { commune and tricuspid } \\
\text { and mitral anomalies. }\end{array}$ \\
\hline $\begin{array}{l}2 \\
3\end{array}$ & $\begin{array}{r}4 \\
10\end{array}$ & $\begin{array}{l}13 \cdot 8 \\
20 \cdot 0\end{array}$ & $\begin{array}{l}\text { Large VSD. } \\
\text { Large VSD and other } \\
\text { right-to-left shunt. At }\end{array}$ & $\begin{array}{l}\text { Closure } \\
\text { Division }\end{array}$ & $\begin{array}{l}21 \\
15\end{array}$ & $\begin{array}{l}600 \\
700\end{array}$ & $\begin{array}{l}\text { Recovery } \\
\text { Recovery }\end{array}$ \\
\hline 4 & $17 \mathrm{mo}$. & $5 \cdot 9$ & $\begin{array}{l}\text { operation, large ductus } \\
\text { Pulmonary stenosis and } \\
\text { ASD. At operation, in- } \\
\text { fundibular stenosis and } \\
\text { ASD (pencil-sized) }\end{array}$ & None & 20 & 300 & $\begin{array}{l}\text { Death end of operation } \\
\text { (cardiac arrest), regular } \\
\text { thickening of pulm. in- } \\
\text { fund., very small ASD, } \\
\text { corda, pap. muscle, } \\
\text { myocard. and valve } \\
\text { anomalies. }\end{array}$ \\
\hline 5 & 5 & $16 \cdot 0$ & Large VSD & Closure & 20 & 650 & $\begin{array}{l}\text { Death 36th hour (heart } \\
\text { failure and cardiac ar- } \\
\text { rest). VSD re-opened } \\
\text { (stitches cut through). } \\
\text { ASD small }\end{array}$ \\
\hline
\end{tabular}

Our experience illustrates the difficulty and importance of accurate diagnosis before operation in cases of complex congenital heart disease. For example, in Case 1, the clinical diagnosis was a large atrial septal defect, but operation revealed, in addition, a persistent common atrio-ventricular canal with malformed mitral and tricuspid valves. In Case 3, the clinical diagnosis was ventricular septal defect with pulmonary hypertension, but at operation the ventricular septum proved to be intact and a large patent ductus was found. In Case 4, the clinical diagnosis was atrial septal defect with infundibular pulmonary stenosis, but at operation the pulmonary tract seemed quite patent: at necropsy, the wall of the infundibulum was diffusely thickened and fibrous, and the condition did not appear to be amenable to surgical correction. Ventricular septal defects were closed in two cases, but in both some of the sutures cut out so that complete closure was not obtained, and it seemed likely that this will often happen when the defect is large.

Since this paper was read, we have operated successfully on a sixth case, a girl aged 10, with pulmonary valvular stenosis and retarded physical development. The pulmonary artery was 
opened and the three fused commissures were divided with scissors. After operation, the systolic murmur was modified and a pulmonary diastolic murmur was heard, but this disappeared two months later.

\section{CONCLUSIONS}

Bad-risk cases were purposely chosen for our first surgical trials: as yet our experience is insufficient to be decisive, but both experimental and clinical trials suggest the following conclusions.

The pump-oxygenator-system provides a valuable method of open heart surgery. Our failures arose from surgical or transfusion difficulties and not from any defect of the pump-oxygenator. Now that an extra-corporeal circulation is applicable to adults, we envisage an extension of open heart surgery to acquired heart disease.

Intracardiac surgery encounters two great difficulties: first that of accurate diagnosis before operation and, secondly, the occurrence of multiple lesions that may be beyond the scope of surgical correction. At present, open heart surgery is in its infancy, but new techniques may well improve its results and widen its scope. If the risks are still high, the stakes are great, and the future is promising.

We are greatly indebted to our technical staff, especially R. Rouilloud and L. Aime, for their valuable help both in our experimental and clinical work.

\section{REFERENCES}

Andreasen, A. T., and Watson, F. (1952). Brit. J. Surg., 39, 548.

Bigelow, W. G., and MacBirnie, J. E. (1953). Ann. Surg., 137, 361.

Cohen, M., and Lillehei, C. W. (1954). Surg. Gynec. Obstr., 98, 225.

Dubost Ch., Nahas, G., Espagno, M., Esclavissat, M., and Schlessler, W. (1955). Press. Méd., 63, 395.

Jones, R. E., Donald, D. E., Swan, H. J. C., Harshberger, H. G., Kirklin, J. W., and Wood, E. H. (1955). Proc. Staff Meet. Mayo Clin., 30, 105.

Lenfant, G., Weiss, M., and Dubost, Ch. (1956). Presse Méd., 64, 382.

1, Rouanet, J., De Wall, R., Nahas, G., and Dubost, Ch. (1956). Presse Méd., 64, 869.

Lillehei, C. W., Baranofsky, I. D., and Varco, R. L. (1952). Bull. Univ. Hosp. Minn. Med. Found., 24, 75.

二; Cohen, M., Warden, H. E., and Varco, R. L. (1955). Surgery, 38, 11.

Nahas, G. G., Weiss, M., and Lenfant, C. (1956). Presse Méd., 5, 84. 